\title{
Hepatitis $B$ vaccination for international travelers to Asia
}

\author{
Kittiyod Poovorawan ${ }^{1}$, Ngamphol Soonthornworasiri ${ }^{2}$, Patiwat Sa-angchai ${ }^{2}$, Chayasin Mansanguan ${ }^{1}$ \\ and Watcharapong Piyaphanee ${ }^{1 *}$
}

\begin{abstract}
There is a wide range in prevalence of hepatitis B virus (HBV) infection and HBV immunization programs between different regions. Hepatitis $B$ is a vaccine preventable disease yet is still endemic in the majority of countries in Asia. Despite the decreasing global prevalence of chronic HBV infection, there is still considerable risk of HBV infection among international travelers to high endemic areas. Numbers of international travelers are expected to increase year by year; thus immunization among this cohort is a crucial preventive measure. Among international travelers to Asia, HBV immunization should be recommended for those without previous HBV vaccination who plan to travel to countries with intermediate to high prevalence of HBV, and especially for those individuals at greater risk of HBV infection; including travelers engaging in casual sex, getting a tattoo or piercing, and those having dental surgery or other medical procedures. Longer duration of travel is also associated with a greater risk of HBV infection. Travelers from low HBV prevalence countries, especially those born before implementation of universal HBV vaccination, might benefit from HBV vaccination during long-term traveling to HBV intermediate to high endemic country.
\end{abstract}

Keywords: Hepatitis B, Travelers, Prevalence, Vaccination, Asia, Immunization programs

Abbreviations: EPI, Expanded program of immunization; HBsAg, Hepatitis B surface antigen; HBV, Hepatitis B virus

\section{Background}

Viral hepatitis is now one of the major causes of death through communicable disease [1]. WHO estimates that 240 million people currently have chronic hepatitis $B$ virus (HBV) infection [2]. HBV infection accounts more than 1 million deaths worldwide from cirrhosis, liver failure, and hepatocellular carcinoma [3]. Despite advances in treatment, eradication of the hepatitis B virus from patients with chronic hepatitis B is rarely achieved [4]. Prevention through vaccination is vital to control HBV infection.

Data from the GeoSentinel Surveillance Network shows that the most common vaccine preventable diseases among travelers returning home ill were enteric fever, acute viral hepatitis and influenza. Hepatitis B infection was the fourth most common after enteric fever, acute hepatitis A and influenza [5]. A study of Australian and European travelers found that approximately $30-65 \%$ of

\footnotetext{
* Correspondence: watcharapong.piy@mahidol.ac.th

${ }^{1}$ Department of Clinical Tropical Medicine, Faculty of Tropical Medicine,

Mahidol University, Bangkok, Thailand

Full list of author information is available at the end of the article
}

travelers to HBV endemic countries undertook activities that potentially exposed them to HBV [6, 7]. Furthermore, less than half of the travelers ( $46 \%$ ) had been vaccinated against HBV [6]. The HBV vaccination rate of people travelling abroad is different in each region [8]. There are many reasons why people did not opt for pre-travel vaccinations, these include the traveler's lack of awareness regarding the prevention of diseases during overseas travel, the limited number of healthcare vaccination facilities and that some countries have yet to approve a number of vaccines needed by travelers [9]. This review aims to explore the need for $\mathrm{HBV}$ vaccination among international travelers to Asia.

\section{International travelers to Asia}

Asia is one of the major global tourist destinations, with more than 263 million international tourist arrivals in 2014 [10]. Six of the top ten most visited cities were located in Asia [11]. China received more than 55 million visits in 2014, making it the most visited country in Asia that year [10]. Most tourist countries in Asia have intermediate to high HBV prevalence. Most of these countries 
Table 1 Prevalence of chronic hepatitis B and coverage of expanded program on HBV immunization in Asian countries receiving a high number of travelers [10, 12, 14]

\begin{tabular}{|c|c|c|c|c|c|c|}
\hline Arrival Country & $\begin{array}{l}\text { International traveler's } \\
\text { arrivals per year (2014) }\end{array}$ & $\begin{array}{l}\text { Estimated prevalence } \\
\text { of chronic hepatitis B } \\
\text { infection }^{\text {a }}\end{array}$ & $\begin{array}{l}\text { Estimated HBsAg } \\
\text { positive population }\end{array}$ & $\begin{array}{l}\text { Implement of Expanded } \\
\text { program of immunization } \\
\text { (EPI) for HBV (Year) }\end{array}$ & $\begin{array}{l}\text { Complete HBV } \\
\text { vaccination at } \\
\text { year } 2014(\%)\end{array}$ & $\begin{array}{l}\text { Population age } \\
\text { after EPI deployed } \\
\text { at year } 2016\end{array}$ \\
\hline China & $55,622,000$ & $5.49 \%$ & $74,601,204$ & 2000 & 99 & 16 \\
\hline Malaysia & $27,437,000$ & $0.74 \%$ & 208,540 & 1989 & 96 & 27 \\
\hline Thailand & $24,780,000$ & $6.42 \%$ & $4,260,008$ & 1992 & 99 & 24 \\
\hline Saudi Arabia & $15,098,000$ & $3.18 \%$ & 866,675 & 1990 & 98 & 26 \\
\hline South Korea & $14,202,000$ & $4.36 \%$ & $2,111,914$ & 1995 & 99 & 21 \\
\hline Japan & $13,413,000$ & $1.02 \%$ & $1,294,431$ & No & No & 0 \\
\hline Singapore & $11,858,000$ & $4.09 \%$ & 207,943 & 1990 & 97 & 26 \\
\hline Indonesia & $9,435,000$ & $1.86 \%$ & $4,468,684$ & 1992 & 78 & 24 \\
\hline India & $7,703,000$ & $1.46 \%$ & $17,553,389$ & 2004 & 70 & 12 \\
\hline Vietnam & $7,874,000$ & $10.79 \%$ & $9,607,438$ & 2003 & 95 & 13 \\
\hline Philippines & $4,833,000$ & $4.63 \%$ & $4,326,212$ & 1995 & 79 & 21 \\
\hline Cambodia & $4,503,000$ & $4.05 \%$ & 581,596 & 2006 & 97 & 10 \\
\hline Jordan & $3,990,000$ & $1.86 \%$ & 119,919 & 1995 & 98 & 18 \\
\hline Myanmar & $3,081,000$ & $3.40 \%$ & $1,765,643$ & 2003 & 75 & 13 \\
\hline Laos & $2,510,000$ & $8.74 \%$ & 558,710 & 2003 & 88 & 13 \\
\hline
\end{tabular}

Estimated at year 2015 based on data on prevalence of chronic HBV infection published between Jan 1, 1965, and Oct 23, 2013 ${ }^{\mathrm{a}}$

Table 2 Prevalence of CHB and coverage of expanded program on HBV immunization in international traveler's to Asia departure countries outside Asia [12-14]

\begin{tabular}{|c|c|c|c|c|c|c|c|}
\hline Region & Country & $\begin{array}{l}\text { International } \\
\text { traveler's departures } \\
\text { per year (2013) }\end{array}$ & $\begin{array}{l}\text { Estimated prevalence } \\
\text { of chronic hepatitis B } \\
\text { infection }^{a}\end{array}$ & $\begin{array}{l}\text { Estimated } \\
\text { HBsAg positive } \\
\text { population }\end{array}$ & $\begin{array}{l}\text { Start of Expanded } \\
\text { Program of Immunization } \\
\text { (EPI) for HBV (Year) }\end{array}$ & $\begin{array}{l}\text { Complete HBV } \\
\text { vaccination (\%) }\end{array}$ & $\begin{array}{l}\text { Number of years } \\
\text { since EPI deployed, } \\
\text { at year } 2016\end{array}$ \\
\hline \multirow[t]{2}{*}{ N. America } & USA & $61,569,000$ & $0.27 \%$ & 843,724 & 1993 & 90 & 23 \\
\hline & Canada & $32,977,000$ & $0.76 \%$ & 260,865 & 2003 & 75 & 13 \\
\hline \multirow[t]{2}{*}{ S. America } & Mexico & $15,911,000$ & $0.20 \%$ & 237,858 & 2000 & 84 & 16 \\
\hline & Argentina & $7,544,000$ & $0.77 \%$ & 312,806 & 2002 & 94 & 14 \\
\hline \multirow[t]{9}{*}{ Europe } & United Kingdom & $58,510,000$ & $0.01 \%$ & 3,300 & Not started & N/A & N/A \\
\hline & Russia & $54,069,000$ & $2.73 \%$ & $3,926,499$ & 2001 & 97 & 15 \\
\hline & Italy & $27,798,000$ & $2.52 \%$ & $1,522,546$ & 1991 & 94 & 25 \\
\hline & France & $26,243,000$ & $0.26 \%$ & 165,728 & 1998 & 82 & 18 \\
\hline & Ukraine & $23,761,000$ & $1.45 \%$ & 666,280 & 2000 & 46 & 16 \\
\hline & Netherlands & $18,094,000$ & $0.40 \%$ & 67,009 & 2013 & 95 & 2 \\
\hline & Hungary & $15,997,000$ & $0.53 \%$ & 53,301 & Not started & $\mathrm{N} / \mathrm{A}$ & N/A \\
\hline & Sweden & $15,917,000$ & $0.59 \%$ & 55,606 & 2011 & 42 & 5 \\
\hline & Spain & $11,246,000$ & $0.34 \%$ & 158,287 & 1996 & 96 & 20 \\
\hline \multirow[t]{2}{*}{ Oceania } & Australia & $8,768,000$ & $0.37 \%$ & 83,121 & 2001 & 91 & 15 \\
\hline & New Zealand & $2,193,000$ & $4.11 \%$ & 179,357 & 1992 & 93 & 24 \\
\hline \multirow[t]{2}{*}{ Africa } & South Africa & $5,168,000$ & $6.70 \%$ & $3,445,477$ & 1997 & 74 & 19 \\
\hline & Uganda & 378,000 & $9.19 \%$ & $3,123,886$ & 2002 & 78 & 14 \\
\hline
\end{tabular}

${ }^{a}$ Estimated at year 2015 based on data on prevalence of chronic HBV infection published between Jan 1, 1965, and Oct 23, 2013 
have implemented universal HBV vaccination. However, vaccine coverage and completeness, measured by delivery of all three doses, of HBV vaccination are still limited in some countries [12]. Furthermore, the majority of those receiving immunization tend to be the young population who were born after the initiation of WHO's Expanded Program on Immunization (EPI) (Table 1).

A large proportion of international travelers to Asia depart from Europe and North America [13]. Most countries in those regions are classified as low HBV prevalence [14]. Therefore many countries do not have universal HBV vaccination [12]. Overall prevalence of hepatitis B infection and coverage of the Expanded Program on HBV Immunization in selected countries with high international traveler's departures to Asia is summarized in Table 2.

\section{Risk of HBV infection during travel}

HBV transmission routes in travelers are through percutaneous or mucosal exposure of HBV-infected blood or bodily fluids including saliva or semen; via sexual contact, contaminated blood products, contaminated medical equipment, and via sharing needles and injecting apparatus [15]. In people using needles contaminated with HBV, the risk of developing infection is approximately $30 \%$ [16]. These routes are different from the usual routes of transmission in high prevalence areas where vertical transmission, when an infected mother transmits the infection to her offspring, is most common [17].

Travelers such as expatriates, those visiting friends and relatives, and travelers engaging in casual sex, dental surgery, and medical procedures may be at greater risk of HBV infection [6]. Younger travelers and those travelers with a longer duration of travel are also at greater risk of HBV infection $[18,19]$. A study of international backpackers in Thailand, found that $25 \%$ of those travelers had had casual sex while travelling and almost half did not always use condom [20]. A study of Dutch travelers to tropical and sub-tropical destinations found that the risk of infection from unprotected sex increased with the number of partners and the incidence of unprotected sex was higher among single travelers [21]. A study by Leggat PA, et al., showed that about half of Australian travelers had participated in at least one activity with a HBV risk during their last overseas trip to Southeast or East Asia [22]. Non-immune travelers traveling to high

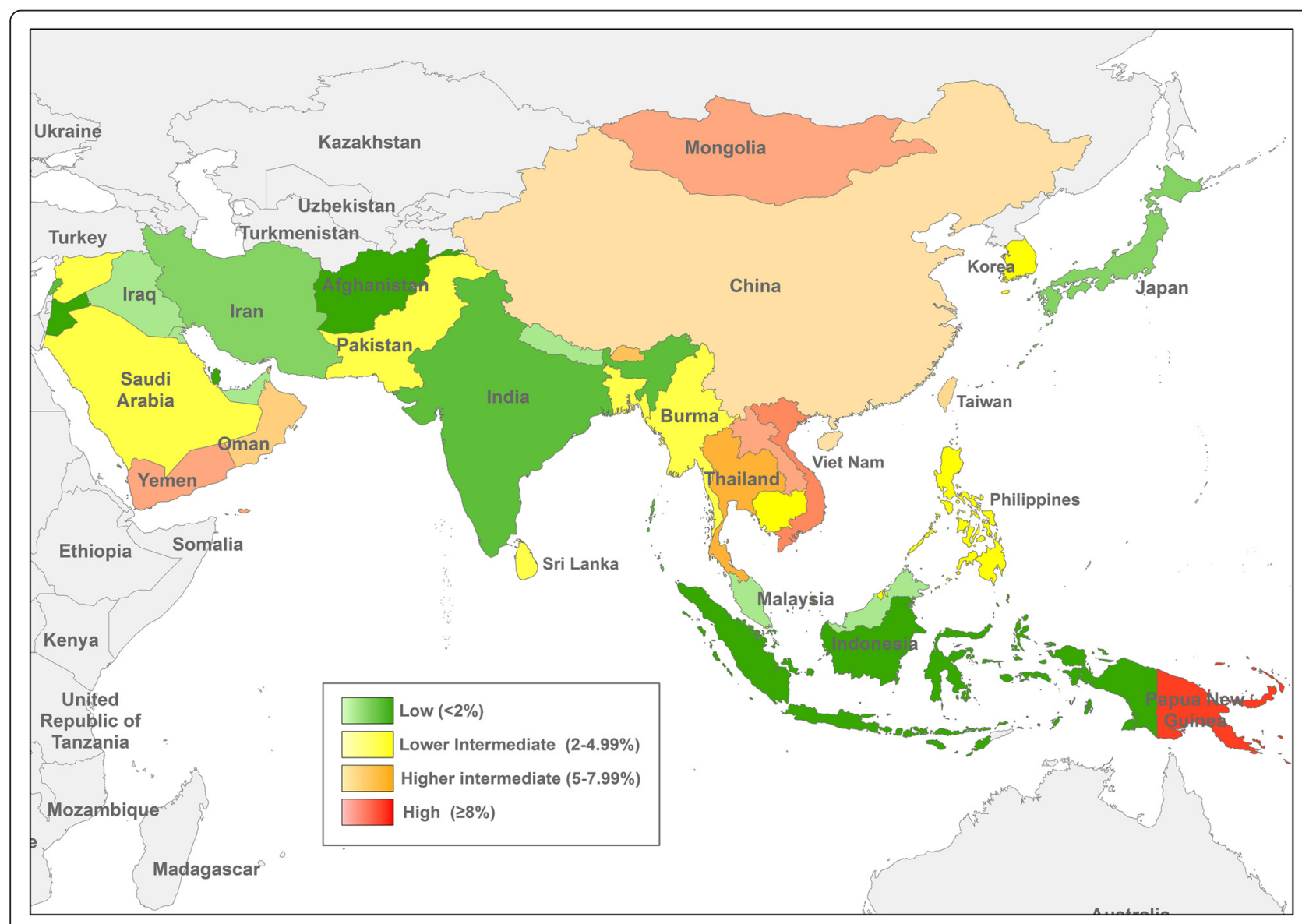

Fig. 1 Estimated prevalence of chronic hepatitis B infection in Asia at 2015 

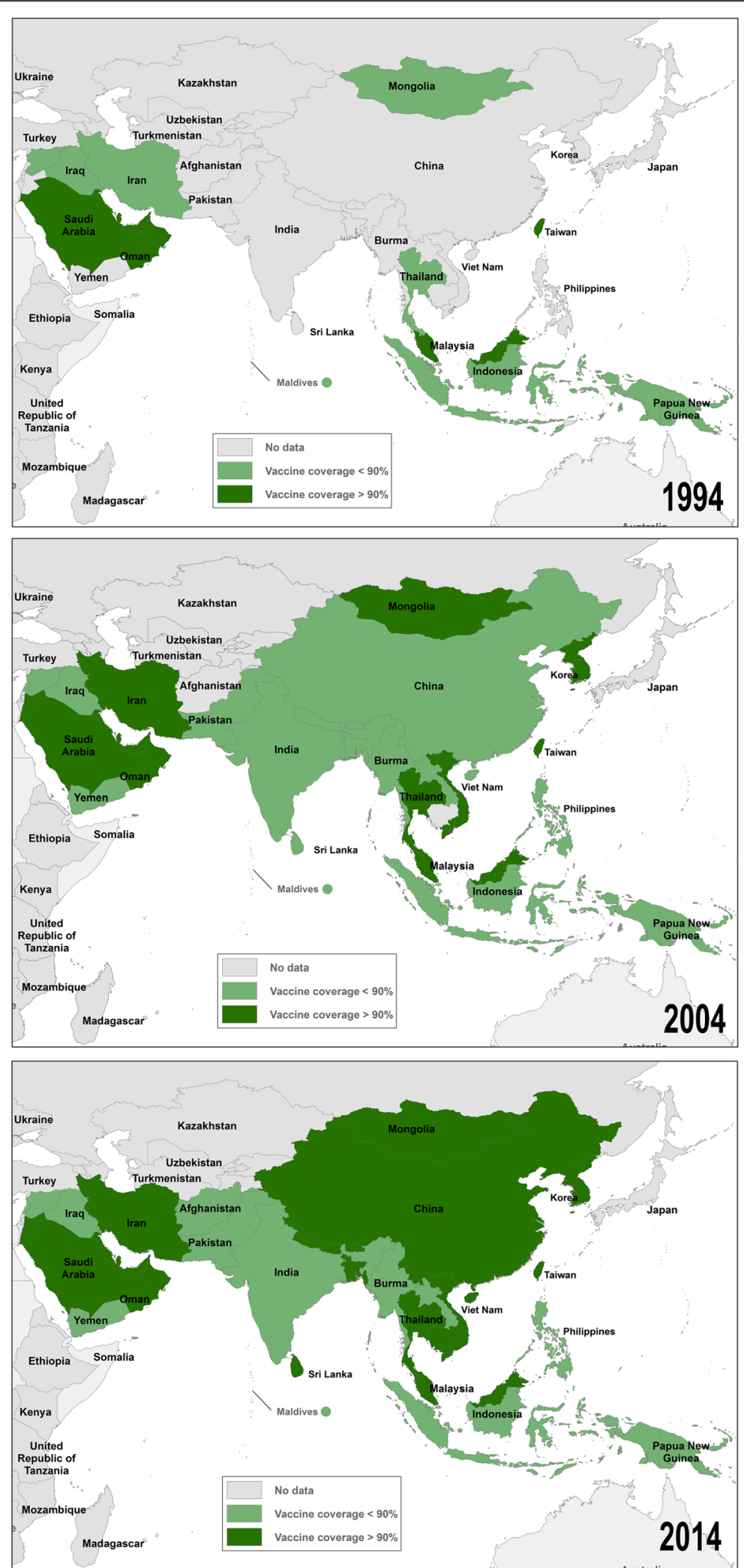

Fig. 2 Estimated coverage of HBV vaccination in Asia in 1994, 2004, 2014 
$\mathrm{HBV}$ prevalence countries might be at risk of $\mathrm{HBV}$ infection due to the many potential accidental and uncontrollable exposures during travel.

\section{Prevalence of HBV infection in Asia}

HBsAg seroprevalence is estimated to be around $3.61 \%$ worldwide. The seroprevalence varies in different regions, with the lowest rates in North America and the highest in Africa. Overall prevalence of HBV infection in Asia is estimated to be $5.26 \%$, with rates varying between countries [14]. Estimated prevalence of chronic hepatitis $\mathrm{B}$ infection in Asian countries receiving a high number of travelers is summarized in Table 1. HBV infection is highly endemic in Southeast Asia and China with a rate of chronic infection of $7-10 \%$ among the general population in these areas $[23,24]$. Prevalence of $\mathrm{HBV}$ infections are classified as low $(<2 \%)$, low intermediate (2-4.99\%), high intermediate (5-7.99\%) and high ( $\geq 8 \%$ ). Estimates based on published data of prevalence of HBV infections from 1965 to 2013 show many countries in Asia to be intermediate to high endemic (Fig. 1) [14]. Based on recent data, Mongolia, Laos, Vietnam and Papua New Guinea are classified with having high prevalence of chronic hepatitis B infection [14].

A study by Posuwan $\mathrm{N}$, et al. showed that the prevalence on HBsAg positive subjects in Thailand decreased from 5$6 \%$ to less than $1 \%$ by 2014, after the implementation of EPI in 1992 [17]. Studies from Luo Z et al., Mohammadi Z, et al. and $\mathrm{Kim} \mathrm{H}$, et al. have also shown the impact of EPI through documenting the decreasing prevalence of $\mathrm{HBV}$ infection in China, Iran and Korea [23, 25, 26].

Universal HBV vaccination was recommended by World Health Organization (WHO) in 1997 [27]. In the 20 years that followed, almost all countries in Asia incorporated $\mathrm{HBV}$ vaccination into their national infant immunization programs [12]. In 2014, WHO and UNICEF estimated $62 \%$ of countries in Asia had achieved more than $90 \%$ coverage of completed (three doses) HBV vaccination (Fig. 2) $[12,28]$. The prevalence of HBV infection and the risk to travelers are likely to decrease as universal vaccination of infants is progressively implemented [29].

Universal HBV vaccination decreases HBsAg seroprevalence in young age groups and vaccine induced protection from HBV infection in the young population

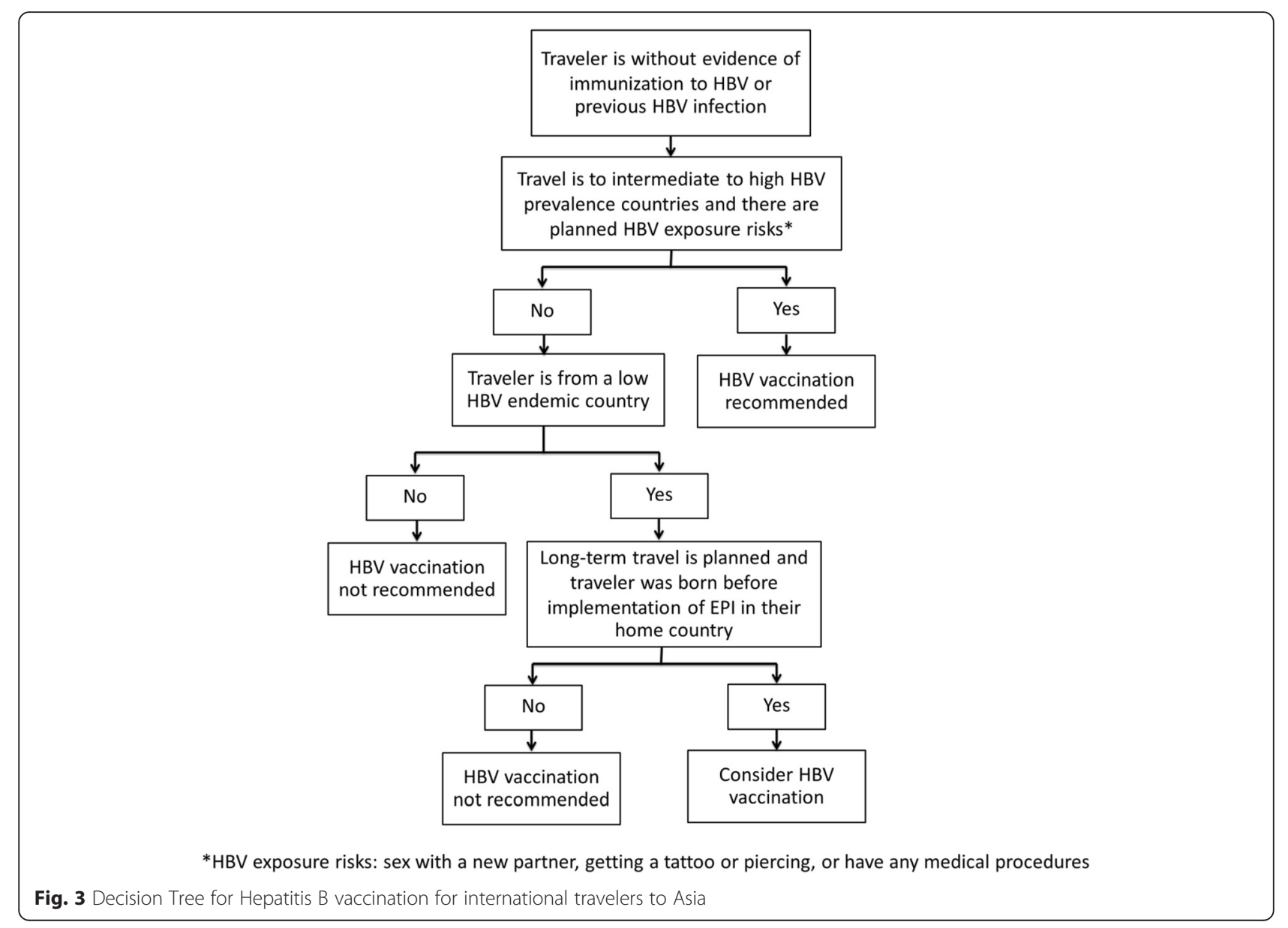


after implementation of universal $\mathrm{HBV}$ vaccination is moderately high (68.5 \%) [17, 30].

Vaccine effectiveness and EPI has led to a strong reduction in HBsAg prevalence in Southeast Asia in the youngest age group (0-14 years) where prevalence levels were $1.2-1.4 \%$ in 2005. In contrast, prevalence in Southeast Asian adults was still high intermediate and this age group is the most likely to interact with travelers [31].

\section{HBV Vaccination for travelers}

Current commercially available hepatitis $B$ vaccines are the recombinant Hepatitis $\mathrm{B}$ vaccine (Engerix- $\mathrm{B}^{\circ}$, GlaxoSmithKline and Recombivax $\mathrm{HB}^{\circ}$, Merck \& Co., Inc.) and the combined hepatitis $\mathrm{A}$ and $\mathrm{B}$ vaccine (Twinrix ${ }^{\circ}$, GlaxoSmithKline). The complete hepatitis $\mathrm{B}$ vaccination needs 3 doses of vaccine. The usual schedule of the three intramuscular injections is to have the second and third administered 1 and 6 months after the first. An accelerated schedule (doses on days $0,7,21$, and then a post-travel dose at 12 months) may be used if there is insufficient time for pre-travel vaccination [32].

HBV prevalence varies between countries, and therefore the number of people acquiring protective immunity from a previous HBV infection also varies. Recommendation of HBV vaccination should be based on likelihood of infection during travel and evidence of previous immunization from either vaccination or recovery from previous infection. In those travelers without evidence of previous HBV immunity, HBV vaccination is recommended in those with HBV exposure risks and travelling to $\mathrm{HBV}$ endemic country.

The US Center of Disease Control and Prevention (CDC) recommends HBV vaccination to all unvaccinated people traveling to areas with intermediate to high prevalence of chronic hepatitis B and suggests it should be considered for all international travelers, regardless of destination, depending on the traveler's potential risk exposure. High risk activities include unprotected sex with a new partner, getting a tattoo or piercing, or having any medical procedures [33].

Despite the CDC recommendation, a study by Connor BA, et al. showed that only $19 \%$ of all American travelers and $30 \%$ of American travelers planning high risk activities had received a completed hepatitis B vaccination before departure [18]. This information is consistent with data from Europe that only $15 \%$ international travelers to $\mathrm{HBV}$ endemic countries receive a completed hepatitis B vaccination before travel [34].

In travelers from low endemic countries and who were born before EPI, the chance of immunity to HBV is very low $[30,35]$. Currently there are no recommendations for HBV serologic screening of international travelers. Due to the high numbers of people it is impractical to screen all international travelers and only 3.4-3.9 \% of the population in low endemic countries will have serologic evidence of prior infection [30,35]. Immunization of those individuals should be considered, especially if long-term travel is planned to countries with intermediate to high prevalence of HBV (Fig. 3).

\section{Conclusions}

Hepatitis B is still endemic in the majority of countries in Asia. HBV infection during travel might occur in those without HBV immunity traveling in an endemic country. This article summarized the updated data that should influence a traveler's decision on whether to get the HBV vaccination before travel to Asia. Vaccination is still the best preventive measure and should be considered by those at risk of $\mathrm{HBV}$ infection during travel.

\section{Acknowledgments}

We would like to express our gratitude to Ms. Nicola Ball and Mr. Argon

Steel of the Office of Research Services, Faculty of Tropical Medicine, Mahidol University, Thailand for their language editing.

Funding

No specific funding granted for this work.

Availability of data and material

Not applicable.

Authors' contributions

KP and WP participated in the design of the study, data collection, data analysis and preparation of the manuscript. NS and CM participated in the data analysis and preparation of the manuscript. PS participated in the data analysis, distribution mapping and preparation of the manuscript. All authors read and approved the final manuscript.

\section{Competing interests}

The authors declare that they have no competing interests.

\section{Consent for publication}

Not applicable.

Ethics approval and consent to participate

Not applicable.

\section{Author details}

${ }^{1}$ Department of Clinical Tropical Medicine, Faculty of Tropical Medicine, Mahidol University, Bangkok, Thailand. ${ }^{2}$ Department of Tropical Hygiene, Faculty of Tropical Medicine, Mahidol University, Bangkok, Thailand.

Received: 4 May 2016 Accepted: 13 August 2016

Published online: 17 August 2016

\section{References}

1. Mortality GBD. Causes of Death C: Global, regional, and national age-sex specific all-cause and cause-specific mortality for 240 causes of death, 1990-2013: a systematic analysis for the Global Burden of Disease Study 2013. Lancet. 2015;385(9963):117-71.

2. WHO. Hepatitis B fact sheet. http://www.who.int/mediacentre/factsheets/ fs204/en/. Accessed 26 April 2016

3. Dienstag JL. Hepatitis B virus infection. N Engl J Med. 2008;359(14):1486-500.

4. Brahmania M, Feld J, Arif A, Janssen HL. New therapeutic agents for chronic hepatitis B. Lancet Infect Dis. 2016;16(2):e10-21.

5. Boggild AK, Castelli F, Gautret P, Torresi J, Von Sonnenburg F, Barnett ED, Greenaway CA, Lim PL, Schwartz E, Wilder-Smith A, et al. Vaccine preventable diseases in returned international travelers: results from the GeoSentinel Surveillance Network. Vaccine. 2010;28(46):7389-95.

6. Streeton $\mathrm{CL}$, Zwar N. Risk of exposure to hepatitis $\mathrm{B}$ and other blood-borne viruses among Australians who travel abroad. J Travel Med. 2006;13(6):345-50. 
7. Zuckerman JN, Steffen R. Risks of hepatitis B in travelers as compared to immunization status. J Travel Med. 2000;7(4):170-4.

8. Pedersini R, Marano C, De Moerlooze L, Chen L, Vietri J. HAV \& HBV vaccination among travellers participating in the National Health and Wellness Survey in five European countries. Travel Med Infect Dis. 2016.

9. Hamada A, Fukushima S. Present situation and challenges of vaccinations for overseas travelers from Japan. J Infect Chemother. 2015;21(6):405-9.

10. UNWTO. Tourism Highlights 2015 Edition.http://www.e-unwto.org/doi/pdf/ 10.18111/9789284416899. Accessed 29 March 2016

11. Euromonitor International. Top 100 city destinations ranking. http://go.euromonitor.com/rs/805-KOK-719/images/TCD-presentation FINAL.pdf. Accessed 29 March 2016

12. WHO/UNICEF. Estimates of national immunization coverage. http://www.who.int/immunization/monitoring_surveillance/routine/ coverage/en/index4.html. Accessed 29 March 2016

13. The World Bank: International tourism, number of departures. http://data. worldbank.org/indicator/ST.INT.DPRT. Accessed 29 March 2016

14. Schweitzer A, Horn J, Mikolajczyk RT, Krause G, Ott JJ. Estimations of worldwide prevalence of chronic hepatitis B virus infection: a systematic review of data published between 1965 and 2013. Lancet. 2015;386(10003):1546-55.

15. Jong EC. Risks of hepatitis A and B in the traveling public. J Travel Med. 2001;8 Suppl 1:S3-8.

16. Werner BG, Grady GF. Accidental hepatitis-B-surface-antigen-positive inoculations. Use of e antigen to estimate infectivity. Ann Intern Med. 1982;97(3):367-9.

17. Posuwan N, Wanlapakorn N, Sa-Nguanmoo P, Wasitthankasem R, Vichaiwattana P, Klinfueng S, Vuthitanachot V, Sae-Lao S, Foonoi M, Fakthongyoo A, et al. The Success of a Universal Hepatitis B Immunization Program as Part of Thailand's EPI after 22 Years' Implementation. PLOS ONE. 2016;11(3), e0150499.

18. Connor BA, Jacobs RJ, Meyerhoff AS. Hepatitis B risks and immunization coverage among American travelers. J Travel Med. 2006;13(5):273-80.

19. Johnson DF, Leder K, Torresi J. Hepatitis B and C infection in international travelers. J Travel Med. 2013;20(3):194-202.

20. Kaehler N, Piyaphanee W, Kittitrakul C, Kyi YP, Adhikari B, Sibunruang S, Jearraksuwan S, Tangpukdee N, Silachamroon U, Tantawichien T. Sexual behavior of foreign backpackers in the Khao San Road area, Bangkok. Southeast Asian J Trop Med Public Health. 2013;44(4):690-6.

21. Whelan J, Belderok S, van den Hoek A, Sonder G. Unprotected casual sex equally common with local and Western partners among long-term Dutch travelers to (sub) tropical countries. Sex Transm Dis. 2013;40(10):797-800.

22. Leggat PA, Zwar NA, Hudson BJ. Hepatitis B risks and immunisation coverage amongst Australians travelling to southeast Asia and east Asia. Travel Med Infect Dis. 2009:7(6):344-9.

23. Luo Z, Li L, Ruan B. Impact of the implementation of a vaccination strategy on hepatitis B virus infections in China over a 20-year period. Int J Infect Dis. 2012;16(2):e82-8.

24. Sa-Nguanmoo P, Tangkijvanich P, Thawornsuk N, Vichaiwattana P. Prianantathavorn K, Theamboonlers A, Tanaka Y, Poovorawan Y. Molecular epidemiological study of hepatitis B virus among migrant workers from Cambodia, Laos, and Myanmar to Thailand. J Med Virol. 2010;82(8):1341-9.

25. Mohammadi Z, Keshtkar A, Eghtesad S, Jeddian A, Pourfatholah AA, Maghsudlu M, Zadsar M, Mahmoudi Z, Shayanrad A, Poustchi H, et al. Epidemiological Profile of Hepatitis B Virus Infection in Iran in the Past 25 years; A Systematic Review and Meta-analysis of General Population Studies. Middle East J Dig Dis. 2016;8(1):5-18.

26. Kim H, Shin AR, Chung HH, Kim MK, Lee JS, Shim JJ, Kim BH. Recent trends in hepatitis B virus infection in the general Korean population. Korean J Intern Med. 2013:28(4):413-9.

27. Van Damme $P$, Kane $M$, Meheus A. Integration of hepatitis B vaccination into national immunisation programmes. Viral Hepatitis Prevention Board. BMJ. 1997:314(7086):1033-6.

28. Burton A, Kowalski R, Gacic-Dobo M, Karimov R, Brown D. A formal representation of the WHO and UNICEF estimates of national immunization coverage: a computational logic approach. PLOS ONE. 2012;7(10), e47806.

29. Rots NY, Wijmenga-Monsuur AJ, Luytjes W, Kaaijk P, De Graaf TW, van der Zeijst BA, Boog CJ. Hepatitis B vaccination strategies tailored to different endemicity levels: some considerations. Vaccine. 2010;28(4):893-900.

30. Roberts H, Kruszon-Moran D, Ly KN, Hughes E, labal K, Jiles RB, Holmberg SD. Prevalence of chronic hepatitis B virus (HBV) infection in U.S. households: National Health and Nutrition Examination Survey (NHANES), 1988-2012. Hepatology. 2016;63(2):388-97.

31. Ott JJ, Stevens GA, Groeger J, Wiersma ST. Global epidemiology of hepatitis $B$ virus infection: new estimates of age-specific HBsAg seroprevalence and endemicity. Vaccine. 2012;30(12):2212-9.

32. Freedman D. Protection of travellers. In: Mandell G, Bennett JE, Dolin R, editors. Mandell, Douglas, and Bennett's principles and practice of infectious diseases. 7th ed. Philadelphia: Churchill Livingstone Elsevier; 2010.

33. CDC Health Information for International Travel 2016. The Yellow Book. 2016.

34. Zuckerman JN, Hoet B. Hepatitis B immunisation in travellers: poor risk perception and inadequate protection. Travel Med Infect Dis. 2008;6(5):315-20.

35. Kiyohara T, Ishii K, Mizokami M, Sugiyama M, Wakita T. Seroepidemiological study of hepatitis B virus markers in Japan. Vaccine. 2015;33(45):6037-42.

\section{Submit your next manuscript to BioMed Central and we will help you at every step:}

- We accept pre-submission inquiries

- Our selector tool helps you to find the most relevant journal

- We provide round the clock customer support

- Convenient online submission

- Thorough peer review

- Inclusion in PubMed and all major indexing services

- Maximum visibility for your research

Submit your manuscript at www.biomedcentral.com/submit
C) Biomed Central 